\title{
IDENTIFICATION OF AN ANTIFUNGAL METABOLITE PRODUCED BY A POTENTIAL BIOCONTROL ACTINOMYCES STRAIN A01
}

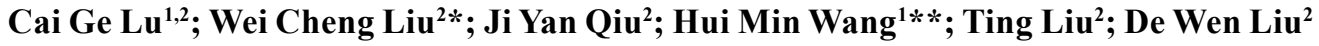 \\ ${ }^{1}$ Department of Plant Pathology, China Agricultural University, Beijing 100094, China; ${ }^{2}$ Institute of Plant and Environment \\ Protection, Beijing Academy of Agriculture and Forestry Sciences, Beijing 100097, China
}

Submitted: September 21, 2007; Returned to authors for corrections: February 20, 2008; Approved: October 22, 2008.

\begin{abstract}
Actinomyces strain A01 was isolated from soil of a vegetable field in the suburb of Beijing, China. According to the morphological, cultural, physiological and biochemical characteristics, and 16S rDNA sequence analysis, strain A01 was identified as Streptomyces lydicus. In the antimicrobial spectrum test strain A01 presented a stable and strong inhibitory activity against several plant pathogenic fungi such as Fusarium oxysporum, Botrytis cinerea, Monilinia laxa, etc. However, no antibacterial activity was found. In pot experiments in greenhouse, the development of tomato gray mold was markedly suppressed by treatment with the fermentation broth of the strain A01, and the control efficacy was higher than those of Pyrimethanil and Polyoxin. A main antifungal compound (purity $99.503 \%$ ) was obtained from the fermentation broth of strain A01 using column chromatography and HPLC. The chemical structural analysis with UV, IR, MS, and NMR confirmed that the compound produced by the strain A01 is natamycin, a polyene antibiotic produced by $S$. chattanovgensis, $S$. natalensis, and S. gilvosporeus, widely used as a natural biological preservative for food according to previous reports. The present study revealed a new producing strain of natamycin and its potential application as a biological control agent for fungal plant diseases.
\end{abstract}

Key words: Streptomyces lydicus, natamycin, fungal plant disease, biological control

\section{INTRODUCTION}

Plant diseases caused by fungi are one of the major reasons for causing agricultural losses (8). Gray mold disease, caused by the fungus Botrytis cinerea, has now become a limiting factor in the vegetable production in many areas of China. The disease used to be and is still being mainly controlled by chemical fungicides, such as aminobenzimidazoles, phthalimide, and carbamates $(28,29)$. However, resistance has been found in B. cinerea to several of these chemicals (24). Furthermore, long term application of chemicals have caused serious food and environment pollutions, and brought attention to the search for alternative measures in controlling plant fungal diseases.
The development and application of microbial agents is one of the alternative measures. Several Streptomyces strains that suppressed the growth of $B$. cinerea were shown to produce antibiotic compounds such as phosphazomyzin, albopeptin B, tautomycin, tautomycein, and ezomycin S (18). The diverse chemical structures of these metabolites would reduce the chance for pathogens to develop resistance (26). In addition, the searching for antimicrobial metabolites has also been spurred on by the possibilities that they could be developed into new classes fungicides $(5,10)$. In the present study, we report a study on the extraction and identification of the metabolic substance of actinomyces strain A01 and its antifungal spectrum and the control efficacy to tomato gray mold under greenhouse conditions.

*Corresponding Author. Mailing address: Institute of Plant and Environment Protection, Beijing Academy of Agriculture and Forestry Sciences, Beijing 100097, China. Phone: +86 10 51503337, Fax: +86 10 51503899. E-mail: liuwccn@yahoo.com.cn

**Departament of Plant Pathology, China Agricultural University, Beijing 100094, China. Phone: +86 10 62733018; Fax: +86 10 62733532. E-mail: wanghm69@cau.edu.cn 


\section{MATERIALS AND METHODS}

\section{Strains}

Actinomyces strain A01 was isolated from the soil of vegetable field in Beijing suburb by the Institute of Plant and Environment Protection, Beijing Academy of Agriculture and Forestry Sciences (IPEP-BAAFS), and has been deposited in the Chinese General Microbiological Collection Centre (Beijing, China) as strain CGMCC No.1653. Fungal pathogens, Fusarium oxysporum f.sp. vasinfectum, $F$. oxysporum f.sp. niveu, $F$. oxysporum f.sp. conglutinans. B.cinerea, Magnaporthe oryzae, Cladosporium fulvum, Exserohilum turcicum, Alternaria solani, Alternaria mali, Monilinia laxa and Colletotrichum capsici were provided by IPEP-BAAFS. The bacterial strains, Agrobacterium rhizogenes, Pseudomonas syringae pv. lachrymans, Bacillus cereus, Xanthomonas vesicatoria and Ralstonia solanacearum, were obtained from Department of Plant Pathology, China Agricultural University. And the yeast strain Saccharomyces cerevisiae (ACCC No. A20063) was obtained from Agricultural Culture Collection of China.

Preparation of the antibiotic fermentation broth of strain A01

Strain A01 was cultured on GAOs no. 1 agar slant (17) at $28^{\circ} \mathrm{C}$ for 2 -wk. The mature spores were washed from the slant with sterilized distilled water and diluted into the suspension in the concentration of $10^{6}$ spores $\mathrm{mL}^{-1}$. Two $\mathrm{mL}$ of this suspension was then inoculated into a $500 \mathrm{~mL}$ Erlenmeyer flask containing $100 \mathrm{~mL}$ fermentation medium (dextrose $2 \mathrm{~g}$, soybean meal $2 \mathrm{~g}$, soluble starch $0.5 \mathrm{~g}$, peptone $0.5 \mathrm{~g}$, corn steep liquor $0.25 \mathrm{~g}$, $\left(\mathrm{NH}_{4}\right)_{2} \mathrm{SO}_{4} 0.25 \mathrm{~g}, \mathrm{MgSO}_{4} \cdot 7 \mathrm{H}_{2} \mathrm{O} 0.025 \mathrm{~g}, \mathrm{~K}_{2} \mathrm{HPO}_{4} 0.002 \mathrm{~g}, \mathrm{NaCl}$ $0.4 \mathrm{~g}, \mathrm{CaCO}_{3} 0.2 \mathrm{~g}$, tap water $100 \mathrm{~mL}$ ) and incubated at $28^{\circ} \mathrm{C}$ on a rotary shaker at $180 \mathrm{rpm}$ for $96 \mathrm{~h}$. The fermented broth was centrifuged at $5,000 \mathrm{~g}, 4^{\circ} \mathrm{C}$ for $15 \mathrm{~min}$, and the supernatant was filtered using a $0.45-\mu \mathrm{m}$-pore-size membrane filter (Millipore). The filtrate was collected as the antibiotic sample.

\section{Bioassay of the antimicrobial activity}

For determining the antimicrobial spectrum, spore suspensions from pathogenic fungi were prepared according to the method described by Soares et al. (22) as follows. Plant pathogenic fungi were cultured on PDA slants (17) at $25-28^{\circ} \mathrm{C}$ for 5-7 d. The fungal spores were harvested by washing with 5 $\mathrm{mL}$ sterilized distilled water and diluted into the suspension in the concentration of $10^{6}$ spores $\mathrm{mL}^{-1}$. About $200 \mu \mathrm{l}$ of the spore suspension was then inoculated onto a PDA plate $(9 \mathrm{~cm}$ in diameter). The plant pathogenic bacteria inoculated on beef peptone agar slants (17), S. cerevisiae on PDA, were cultured at $28^{\circ} \mathrm{C}$ for $2 \mathrm{~d}$, and then washed up and diluted into the suspension in the concentration of $10^{4} \mathrm{CFU} \mathrm{mL} \mathrm{mL}^{-1}$ with sterile physiological salt solution $(0.85 \% \mathrm{NaCl})$ and $5 \mathrm{~mL}$ of the suspension was mixed into $100 \mathrm{~mL}$ molten PDA at $45^{\circ} \mathrm{C} .30 \mathrm{~mL}$ of the mixture was poured into a Petri dish $(9 \mathrm{~cm}$ in diameter) to give a solid plate. Three wells $(7 \mathrm{~mm}$ in diameter) were prepared in each seeded agar plate and each well was filled with $100 \mu$ of the antibiotic fermentation broth of strain A01. The plates were incubated at $25^{\circ} \mathrm{C}$ for $2 \mathrm{~d}$. The diameter of the inhibition zones were measured with a vernier caliper. Each treatment had three replications.

For estimating the antifungal activity of the bioactive extracts dissolved in organic solvents, the paper disc agar diffusion bioassay modified from the method of Valgas et al. (25) was used. The sterile filter paper disk (10 $\mathrm{mm}$ in diameter) was saturated with the bioactive extract solution, and then dried up. Repeat this three times. The paper disk treated with bioactive solution was placed on the surface of a seeded agar plate prepared as described above. The clear inhibition zone around the paper disk was measured after incubation for $2 \mathrm{~d}$ at $25^{\circ} \mathrm{C}$.

\section{Evaluation of the control effect in greenhouse}

Autoclaved soil $\left(121^{\circ} \mathrm{C}\right.$ for $\left.2 \mathrm{~h}\right)$ was mixed with peat moss (1:1) and placed into $5 \times 9 \times 12 \mathrm{~cm}$ plastic pots. Two germinated tomato seeds (Lycopersicon esculentum Mill. cv. Zhongshu No.6) were planted into each pot and grown in a greenhouse at $25 \pm 2^{\circ} \mathrm{C}$ under natural light. The experiment included four treatments: 1) 1:5 dilution of the filtrate from fermented broth of strain A01;2) chemical fungicide Pyrimethanil (Qinggyuanbao Biotech Ltd., Inner Mongolia, China) in the concentration of $500 \mu \mathrm{g} \mathrm{mL}^{-1}$; 3) wettable powder of the fungicide Polymyxin (Yanbian Chunlei Biopharmcieuticals Ltd., China) in the concentration of $30 \mu \mathrm{g} \mathrm{mL}^{-1}$; and 4) water as the negative control. 45 tomato plants for each treatment and three replicates were performed.

Each of the solutions was sprayed on the surface of tomato plants at the first bloom stage. While the surface of the leaves become dry, the plants were sprayed with the spore suspension $\left(10^{6}\right.$ spores $\left.\mathrm{mL}^{-1}\right)$ of $B$. cinerea, and then were placed in an enclosed plastic chamber in which the humidity was kept at $100 \%$ for $48 \mathrm{~h}$. Plants were then incubated at $22^{\circ} \mathrm{C}$ in the greenhouse until symptoms appeared on leaves of the control plants. The disease rate and disease index was surveyed based on the criteria given by Bioassay Division of Institute for the Control of Agrochemicals, Ministry of Agriculture, China (6).

\section{Taxonomic determination of strain A01}

For the morphological characterization, strain A01 was cultured on GYM agar (15) and oatmeal agar (13) at $28^{\circ} \mathrm{C}$ for $7 \mathrm{~d}$, and observed using a microscope (Nikon ECLIPSE TE2000-U, Japan). Cultural characteristics were determined by growing the strain on 6 media namely GAOs no.1 agar, starch agar (13), GYM agar, oatmeal agar, Bennett's agar, and nutrient agar (17) plates at $28^{\circ} \mathrm{C}$ for $2 \mathrm{wk}$ to observe mycelia color and diffusible pigments. The physiological and biochemical characteristics were tested using the media and methods described by Ruan (17) and Shirling \& Gottlieb (19). 
The 16S rDNA sequence of strain A01 was analyzed using the method of Hopwood et al. (12). The PCR was carried out using the universal bacterial $16 \mathrm{~S}$ rDNA primers and the PCR product was sequenced directly with the Taq DyeDeoxy Terminator Cycle Sequencing Kit (Biosystem, INC, USA). Electrophoresis and data collection was performed with an automated DNA Sequencer (model 377, Applied Biosystems, USA). The $16 \mathrm{~S}$ rDNA sequence was assembled and blasted against sequences in the GenBank database to determine the identity.

\section{Purification and chemical characterization of the bioactive substance}

The fermented broth of strain A01 was mixed with $100 \%$ ethanol $(1: 1, \mathrm{v} / \mathrm{v})$ and placed at $4^{\circ} \mathrm{C}$ for $2 \mathrm{~h}$. The mixture was then stirred up and centrifuged at 5,000 $\mathrm{g}$ for $20 \mathrm{~min}$. The supernatant was concentrated at $45^{\circ} \mathrm{C}$ under vacuum. The concentrate was adsorbed into macroporous resin D4006 (Chemical factory of Nankai University, Tianjin, China) and then eluted seriatim with deionized water, $50 \%$ methanol and $80 \%$ ethanol at a rate of 0.5 $\mathrm{mL} \mathrm{min}^{-1}$. The eluent were collected into tubes in fractions of 5 $\mathrm{mL}$ with a BSZ-100 automatic fraction collector (Shanghai Huxi Analytical Instrumentation Factory, Shanghai). After being bioassayed using the paper disc agar diffusion method with $B$. cinerea as the indicator, the active fractions were combined and concentrated under vacuum at $45^{\circ} \mathrm{C}$, then diluted with twice volume of methanol:water $(7: 3, \mathrm{v} / \mathrm{v})$ and separated again by using a $26.0 \mathrm{~mm} \times 400 \mathrm{~mm}$ chromatography column of 200 mesh silica gel (Beijing Chemical Reagent Co., Beijing, China) with the mobile phase consisting of chloroform-methanol-water $(2: 3: 1, \mathrm{v} / \mathrm{v} / \mathrm{v})$. The eluent was collected, concentrated and bioassayed again. The active fractions were finally separated by a cycled preparative HPLC (Japan Analytical Industry Co., Ltd., Japan) with C18 reverse phase column (LC-9101-JAIGEL-ODS, Japan), using the mobile phase of $70 \%$ methanol (Fisher, USA) at a rate of $3 \mathrm{~mL} \mathrm{~min}^{-1}$, and monitored at $305 \mathrm{~nm}$ with a UV detector (JAI UV 3702, Japan). The fractions corresponding to each absorption peak were collected separately with a fraction collector (JAI FC-206, Japan) and bio-assayed. The main active fraction was picked out as the terminal sample and concentrated with a SpeedVac centrifuging concentrator (Thermo SPD1010, USA). The purity of the concentrate was examined using analytical HPLC (LC-10AT, Shimadzu Corporation, Japan) with analytical $\mathrm{C} 18$ reverse phase column.

The chemical structure of the terminal antimicrobial compound was determined with spectroscopy methods. The nuclear magnetic resonance (NMR) analysis was performed using a Bruker AVANCE DRX-500 NMR spectrometer (Bruker Instruments Inc., Germany) with N, N-dimethylformamide (dDMF) as a solvent. High resolution FT-mass spectrometry was conducted using a 9.4T Apex Q-FT-MS spectrometer (Bruker Instruments Inc., Germany) under the following conditions: capillary $4000 \mathrm{v}$, dry gas $4.0 \mathrm{~L} / \mathrm{s}$, ion source temperature $180^{\circ} \mathrm{C}$, scan range 300-2000 amu, syringe pump $1.5 \mathrm{~mL} \mathrm{~min}^{-1}$. The infrared spectrum within $4000 \mathrm{~cm}^{-1}-400 \mathrm{~cm}^{-1}$ was measured using a Tensor 27 Nicolet spectrometer (Bruker Instruments Inc., Germany), and the ultra-violet spectrum within 190-400 nm using a UV-VIS 3010 spectrophotometer (Hitachi Ltd., Japan).

\section{Statistical analysis}

The experiment data of the antimicrobial activities in vitro and control efficacies to tomato gray mold in greenhouses were analyzed using SPSS 13.0 for Windows.

\section{RESULTS}

\section{The antimicrobial spectrum of A01}

The result of mycelial growth inhibition assay showed that the fermented broth of strain A01 presented a strong inhibitory activity against all of the 14 plant pathogenic fungi and one yeast $S$. cervisiae tested in the experiment (Table 1). The average diameter of inhibition zones for the pathogens (about $4.0 \mathrm{~cm}$ ) was greater than that for the yeast (about $3.0 \mathrm{~cm}$ ). Especially the inhibition zone for the pathogens M. laxa and E. turcicum reached respectively up to $4.8 \mathrm{~cm}$ and $4.7 \mathrm{~cm}$. However, no antibacterial activity was found against the tested bacteria.

\section{The control effect in greenhouse}

Five days after being inoculated with $B$. cinerea, the plants treated with Pyrimethanil and water were wilted, some leaves were chlorotic, covered with gray mold in some surface areas, and fall off. While the negative control plants were severely

Table 1. Antifungal activities of fermentation broth of strain A01.

\begin{tabular}{lc}
\hline \multicolumn{1}{c}{ Pathogens } & $\begin{array}{c}\text { Average inhibition } \\
\text { diameter }(\mathrm{cm})\end{array}$ \\
\hline Fusarium oxysporum f. sp. vasinfectum & $4.30 \pm 0.00$ \\
Fusarium oxysporum f. sp. niveum & $4.13 \pm 0.07$ \\
Fusarium oxysporum. f. sp. conglutinans & $4.47 \pm 0.03$ \\
Botrytis cinerea (on grape) & $4.30 \pm 0.00$ \\
Botrytis cinerea (on tomato) & $4.03 \pm 0.03$ \\
Botrytis cinerea (on eggplant) & $4.50 \pm 0.00$ \\
Pyricularia oryzae & $4.00 \pm 0.00$ \\
Cladosporium fulvum & $4.40 \pm 0.00$ \\
Exerphilum turcicum & $4.63 \pm 0.03$ \\
Alternaria solani & $4.50 \pm 0.00$ \\
Monilinia laxa & $4.77 \pm 0.03$ \\
Alternaria mali & $4.07 \pm 0.07$ \\
Colletotrichum capsici & $4.10 \pm 0.00$ \\
Saccharomyces cerevisiae & $2.97 \pm 0.09$ \\
\hline
\end{tabular}


diseased, there was a reduction in the level of severity in the plants treated with this fungicide (about 80 vs 45 disease index, Table 2). However, all plants died 10 days after treatment in both cases. In contrast plants sprayed with Polyoxin and the fermented broth of strain A01 had much lower levels of disease incidence than control plants (about 100 vs 35, respectively) and lower disease severities (about 80 vs 15). Both the fungicide and the filtrate provided about $85 \%$ disease reduction.

\section{Taxonomic classification of strain A01}

The cultural, biochemical and physiological characteristics of strain A01 are typical properties of genus Streptomyces (Table 3 and Table 4). A 1,270 bp 16S rDNA partial sequence of strain A01 was determined. The DNA sequence was deposited in GenBank under accession no.EF532323. A standard nucleotidenucleotide BLAST search (1) against the GenBank database using this sequence showed that there is the highest homology in the 16S rDNA sequence between strain A01 and S. lydicus Y15507.1. According to the polyphasic studies, strain A01 was identified as S. lydicus.

\section{Purification and structure elucidation of the antifungal compound}

The results of the bioassay showed that the active constituents were mainly collected from the mobile phase of $80 \%$ ethanol in the case of the macroporous resin separation and the adjacent fractions of the eluate of chloroform-methanolwater $(2: 3: 1, \mathrm{v} / \mathrm{v} / \mathrm{v})$ from the silica gel column. The active fractions resulted in 6 peaks on the first HPLC separation spectrum, and the fraction corresponding to the peak appearing at the elution time of $57.399 \mathrm{~min}$ was identified as the active one. The active fraction was separated again by second HPLC. A fraction with higher activity was obtained as the terminal constituent, which corresponded to the peak at the elution time of 38.399 min on the last HPLC spectrum. Only one peak was
Table 3. Cultural characteristics of strain A01 on different media.

\begin{tabular}{lcccc}
\hline Agar media Growth & $\begin{array}{c}\text { Aerial } \\
\text { mycelium }\end{array}$ & $\begin{array}{c}\text { Substrate } \\
\text { mycelium }\end{array}$ & $\begin{array}{c}\text { Soluble } \\
\text { pigments }\end{array}$ \\
\hline GAOs no.1 & ++ & white/gray & yellow & light yellow \\
Bennett's & ++ & light gray & brown & light yellow \\
Nutrient & ++ & gray & light brown & none \\
GYM & ++ & light gray & brown & yellow \\
Oatmeal & ++ & gray & light brown & light brown \\
Starch & ++ & white /gray & brown & light yellow \\
\hline
\end{tabular}

Note: +++ , very well; ++ , well.

detected for the terminal constituent by analytical HPLC, which revealed that the constituent contained a single compound. The relative area of the peak suggested a purity up to $99.503 \%$ for the compound, sufficiently meeting the requirement for structural analysis. The terminal active constituent was dried in a vacuum into white powder that was partially soluble in N, Ndimethylformamide (DMF), dimethyl sulphoxide (DMSO), pyridine, acetic acid with water, methanol or ethanol with water, but insoluble in acetone, chloroform, diethyl ether, ethyl acetate, and water.

The UV spectrum showed that the active compound dissolved in methanol-water presented four typical absorbance peaks at wavelengths $281 \mathrm{~nm}, 291 \mathrm{~nm}, 305 \mathrm{~nm}$ and $319 \mathrm{~nm}$, which is the typical characteristic of conjugated polyene chemicals. In the IR spectrum, the peaks at $v>3000 \mathrm{~cm}^{-1}$ indicated that there is a typical carboxyl-structure; the $v=1716 \mathrm{~cm}^{-1}$ peak revealed a conjugated ester; the $v=1570 \mathrm{~cm}^{-1}$ peak corresponded to a primary amine; and the $v=1270-1150 \mathrm{~cm}^{-1}$ peaks showed the existence of different C-O-. The molecular weight 665 and the molecular formula $\mathrm{C}_{33} \mathrm{H}_{47} \mathrm{NO}_{13}$ of the antibiotic compound of

Table 2. Biocontrol effects of fermentation broth of strain A01 against tomato gray mold in greenhouse.

\begin{tabular}{|c|c|c|c|c|c|c|}
\hline Treatment & $\begin{array}{l}\text { Days after } \\
\text { treatment }\end{array}$ & $\begin{array}{c}\text { Disease } \\
\text { rate* }\end{array}$ & & $\begin{array}{c}\text { Disease } \\
\text { index* }\end{array}$ & & $\begin{array}{l}\text { Control } \\
\text { efficacy }\end{array}$ \\
\hline \multirow[t]{2}{*}{ Water } & 5 & $99.4 \pm 0.31$ & $\mathrm{a}$ & $78.5 \pm 0.33$ & $\mathrm{a}$ & \\
\hline & 10 & $99.7 \pm 0.12$ & $\mathrm{a}$ & $82.4 \pm 0.82$ & $\mathrm{a}$ & \\
\hline \multirow[t]{2}{*}{ Pyrimethanil $\left(500 \mu \mathrm{g} \mathrm{mL}^{-1}\right)$} & 5 & $91.9 \pm 0.71$ & $\mathrm{~b}$ & $43.1 \pm 0.65$ & $\mathrm{~b}$ & 45.1 \\
\hline & 10 & $92.9 \pm 0.20$ & $\mathrm{a}$ & $45.7 \pm 0.46$ & $\mathrm{~b}$ & 44.5 \\
\hline \multirow[t]{2}{*}{ Polyoxin $\left(30 \mu \mathrm{g} \mathrm{mL}^{-1}\right)$} & 5 & $29.5 \pm 0.27$ & $\mathrm{e}$ & $13.3 \pm 0.38$ & $\mathrm{c}$ & 83.1 \\
\hline & 10 & $37.9 \pm 1.70$ & $\mathrm{c}$ & $14.5 \pm 0.58$ & $\mathrm{c}$ & 82.4 \\
\hline \multirow[t]{2}{*}{ Fermentation broth } & 5 & $35.1 \pm 0.57$ & d & $8.1 \pm 0.52$ & d & 89.7 \\
\hline & 10 & $33.7 \pm 0.26$ & $\mathrm{c}$ & $14.0 \pm 0.87$ & $\mathrm{c}$ & 83.0 \\
\hline
\end{tabular}

* The data are the average of three replicates \pm SE. Data in the same column followed by the same letter are not significantly different $(\mathrm{P}<0.05)$ according to analysis of variance. 
Table 4. Physiological and biochemical characteristics of strain A01.

\begin{tabular}{lc}
\hline \multicolumn{1}{c}{ Characteristics } & Results \\
\hline Gram stain & + \\
Nitrate reduction & - \\
Melanin production & - \\
$\mathrm{H}_{2}$ S production & - \\
Citrate acidolysis & - \\
Degradation of : & + \\
Gelatin & + \\
Starch & + \\
Urea & - \\
Cellulose & + \\
Esculin & \\
Growth on sole carbon sources: & + \\
Fructose & + \\
Mannose & + \\
Glucose & + \\
Maltose & + \\
Sucrose & + \\
Lactose & + \\
Rhamnose & - \\
Xylose & - \\
Arabinose & - \\
Sorbose & - \\
Growth at: & + \\
$1 \% \mathrm{NaCl}$ & + \\
$3 \% \mathrm{NaCl}$ & + \\
$5 \% \mathrm{NaCl}$ & + \\
$7 \% \mathrm{NaCl}$ & + \\
\hline Fosive & + \\
\hline & \\
\hline
\end{tabular}

Note: + , positive reaction; -, negative reaction.

strain A01 were deduced by high resolution FT - mass spectroscopy (M+Na, m/z 688.2938, calculated 688.2940) (Fig. 1). In the ${ }^{1} \mathrm{H}-\mathrm{NMR}$ spectrum (Fig. 2), the hydrogen on the carboxyl- was neutralized in the solvent DMF, causing the disappearance of peak $\delta=12$ and the presence of two solvent peaks of $\delta=3$ and 8 at the same time; the group of peaks next to $\delta=6$ represented the hydrogen bonded on the conjugated ester, and the group of peaks around $\delta=5$ presented a-OH. In the ${ }^{13} \mathrm{C}$ NMR spectrum (Fig. 3), the peaks of $\delta=180$ and 165 are indicative of the existence of carboxyl and ester groups, the peak of $\delta=130$ was produced by polyethylene, and the most intensive peak was given by the solvent DMF. In addition, COSY, TOCSY, DEPT, NOE, HMBC and HMQC spectrometry were also conducted on the compound. Based on the analysis of NMR data and other chemical characteristics, the antibiotic compound of A01 turned out to have the same structure as natamycin as shown in Fig. 4.

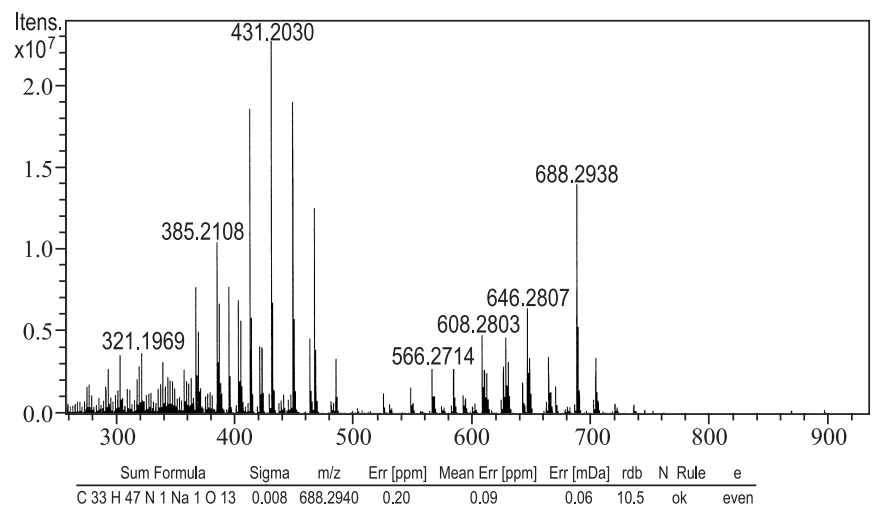

Figure 1. High resolution FT - mass spectrum of the bioactive compound of strain A01.

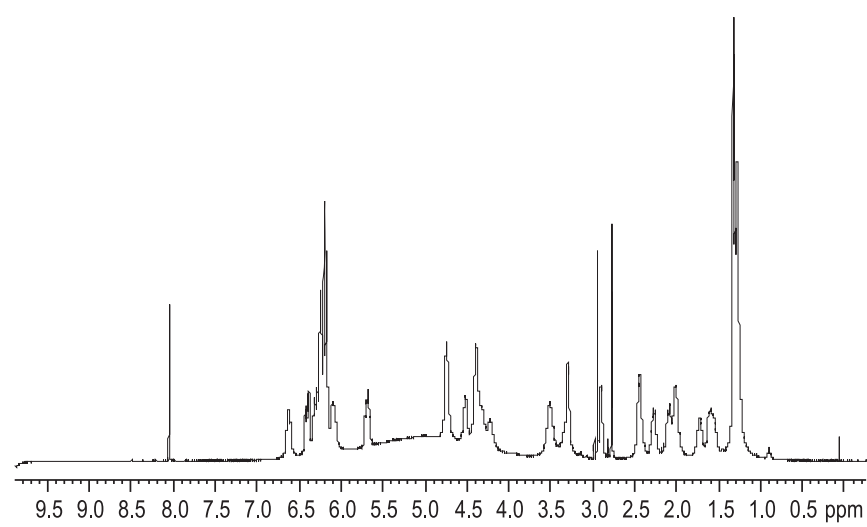

Figure 2. ${ }^{1} \mathrm{H}$ NMR spectrum of the bioactive compound of strain A01 recorded at ${ }^{1} \mathrm{H}-500 \mathrm{MHz}$ and $25^{\circ}$.

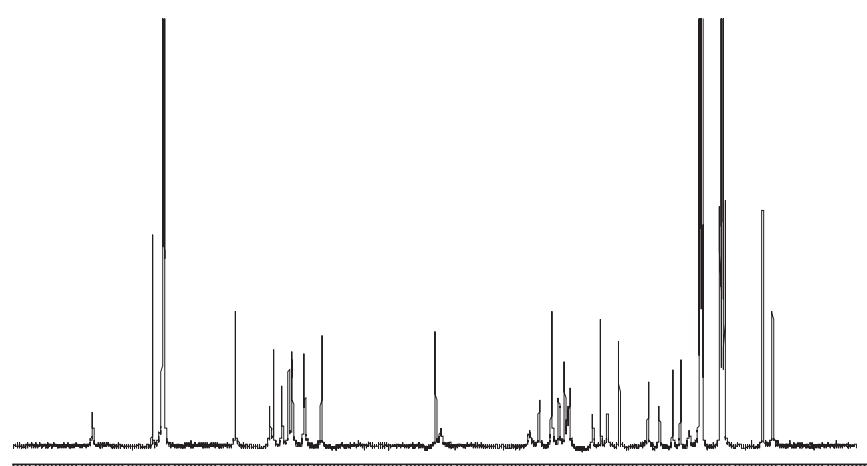

$19018017016015014013012011010090 \quad 80 \quad 70 \quad 60 \quad 50 \quad 40 \quad 30 \quad 20 \quad 10$ ppm

Figure 3. ${ }^{13} \mathrm{C}$ NMR spectrum of the bioactive compound of strain $\mathrm{A} 01$ recorded at ${ }^{13} \mathrm{C}-500 \mathrm{MHz}$ and $25^{\circ}$. 


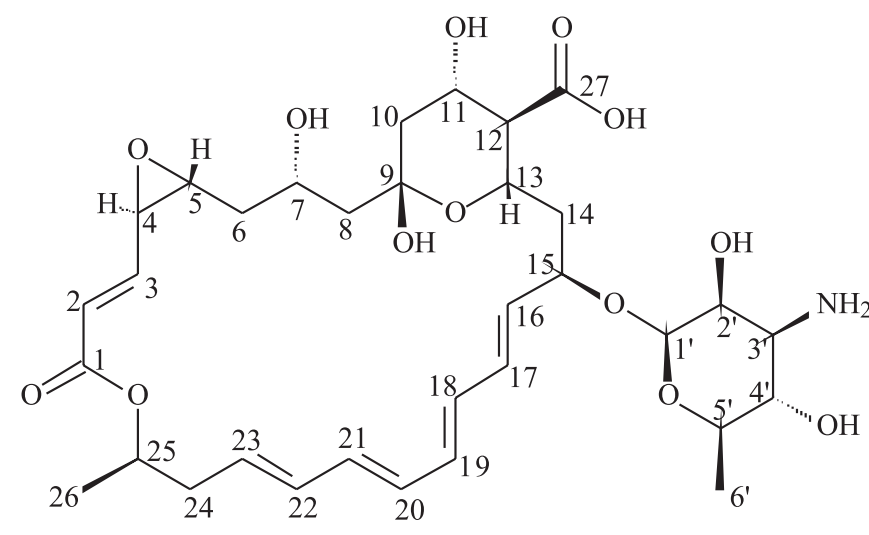

Figure 4. The structure of the bioactive compound of strain A01.

\section{DISCUSSION}

Actinomycetes are major producer of pharmaceuticals and agricultural pesticides due to its ability to produce antibiotics. Among the 10,000 antimicrobial active compounds produced by microorganisms, over $50 \%$ were from Actinomycete (2). Many S. lydicus strains have been reported to produce different types of secondary metabolites, such as Chandramycin (21), Lydicamycin(11), Ganefromycin (7), and Streptolydigin (20). $S$. lydicus WYEC 108 has been studied extensively for agricultural applications in recent years (16). It is produced commercially to control soil-borne and leaf surface diseases in turf and greenhouse crops (27). WYEC108 produces chitinase (14), which functions synergistically with several antibiotics $(9,23)$ to kill other fungi.

In this study, strain A01 presented a strong antifungal effect in vitro and effectiveness in controlling tomato gray mold in pot experiments in greenhouse. On the basis of morphological, cultural, physiological and biochemical characteristics, and $16 \mathrm{~S}$ rDNA sequence analysis, the strain was identified to be $S$. lydicus. It could produce high antifungal substance by liquid fermentation. The chemical structural analysis with UV, IR, MS, and NMR confirmed that the main antifungal compound produced by $\mathrm{A} 01$ is natamycin.

Natamycin is a macrolide polyene antifungal drug, which is widely used for the treatment of fungal keratitis and also in the food industry to prevent mold contamination of cheese and other nonsterile foods (3). Now, it has been used as a natural biological preservative and anti-microbial additive for food in more than 30 countries (4). Up to now, the antibiotic was reported to be produced by $S$. chattanovgensis, $S$. natalensis, and $S$. gilvosporeus. To the best of our knowledge, no documented record indicated that the antibiotic natamycin was produced by S. lydicus, and there is no systematic report on the use of natamycin to control plant fungal diseases.
Our research results revealed that the antibiotic natamycin can be produced by S. lydicus. This provided a new producing microorganism resource for natamycin. Furthermore, the bioactive compound was proved having a broad antifungal spectrum to plant pathogenic fungi. The findings from this study suggest the potential of using natamycin as a biocontrol agent for plant fungal diseases. Further evaluations are needed for the biocontrol efficiency to plant diseases in the fields.

\section{ACKNOWLEDGEMENTS}

This research was jointly supported by the National Natural Scientific Foundation of China (No.30671346), Beijing Natural Scientific Foundation (No.6072010), and Beijing Municipal Science \& Technology Program (D0706005000091 and D0706005040231).

\section{RESUMO}

\section{Identificação de um metabólito antifúngico produzido pela cepa Actinomyces A01}

A cepa Actinomyces A01 foi isolada do solo de um campo agrícola no subúrbio de Beijing, China. De acordo com as características morfológicas, culturais, fisiológicas e bioquímicas, e análise da sequência $16 \mathrm{~S}$ rDNA, a cepa A01 foi identificada como Streptomyces lydicus. Nos testes de espectro antimicrobiano, a cepa A01 apresentou atividade inibitória intensa e estável contra vários fungos patogênicos para plantas, como Fusarium oxysporum, Botrytis cinerea, Monilia laxa, etc. Entretanto, não foi encontrada atividade antibacteriana. Em experimentos em estufas, o desenvolvimento do fungo cinza do tomate foi fortemente inibido pelo tratamento com o caldo de fermentação da cepa A01, com eficiência superior à do pyremethanil e polyoxin. Por cromatografia em coluna e HPLC, obteve-se um composto fúngico (pureza 99,503\%), cuja análise estrutural por UV, IR, MS e NMR revelou ser natamicina, um antibiótico polienico produzido por $S$. chattanovgensis, $S$. natalensis e S.gilvosporeus, empregado como conservador biológico natural em alimentos. O presente estudo relata a detecção de uma nova cepa produtora de natamicina e sua aplicação potencial como um agente de controle biológico de doenças fúngicas em plantas.

Palavras-chave: Streptomyces lydicus, natamicina, doenças fúngicas em plantas, controle biológico

\section{REFERENCES}

1. Altschul, S.F.; Madden, T.L.; Schäffer, A.A.; Zhang, J.; Zhang, Z.; Miller, W.; Lipman, D.J. (1997). Gapped BLAST and PSI-BLAST: a new generation of protein database search programs. Nucleic Acids Res., 25, 3389-3402. 
2. Anderson, A.S.; Wellington, E.M.H. (2001). The taxonomy of Streptomyces and related genera. Int. J. Syst. Evol. Microbiol., 51, 797-814.

3. Anton, N.; Mendes, M.V.; Martin, J.F.; Aparicio, J.F. (2004). Identification of PimR as a positive regulator of pimaricin biosynthesis in Streptomyces natalensis. J. Bacteriol., 186, $2567-$ 2575.

4. Basilico, J.C.; Basilico, M.Z.; Chiericatti, C.; Vinderola, C.G. (2001). Characterization and control of thread mould in cheese. Lett. Appl. Microbiol., 32, 419-424.

5. Betina, V. (1994). Bioactive secondary metabolites of microorganisms. Elsevier. Amsterdam.

6. Bioassay Division of Institute for the Control of Agrochemicals, Ministry of Agriculture, P. R. China (Eds.) (1997). Pesticide guidelines for the field efficacy trials (I)-Standard Press of China, Beijing. p. 45-50.

7. Carter, G.T.; Phillipson, D.W.; West, R.R.; Borders, D.B. (1993). Chemistry and structure of Ganefromycin. J. Org. Chem., 58, 65886595.

8. Cornelissen, B.J.C.; Melchers, L.S. (1993). Strategies for control of fungal diseases with transgenic plants. Plant Physiol., 101, 709-712.

9. Crawford, D.L.; Lynch, J.M.; Whipps, J.M. ; Ousley, M.A. (1993). Isolation and characterization of actinomycete antagonists of a fungal root pathogen. Appl. Environ. Microbial., 59, 3899-3905.

10. Godfrey, C.R.A. (1994). Fungicides and bactericides. In: (Godfrey, C.R.A. Ed.), Agrochemical from natural products. Marcel Dekker Inc., New York. P. 311-340.

11. Hayakawa, Y.; Kanamaru, N.; Shimazu, A.; Seto, H. (1991b). Lydicamycin, a new antibiotic of a novel skeletal type. I. Taxonomy, fermentation, isolation and biological activity. J. Antibiot., 44, 282287.

12. Hopwood, D.A.; Bibb, M.J.; Chater, K.E.; Kieser, T.; Bruton, C.J.; Kieser, H.M.; Lydiate, D.J.; Smith, C.P.; Ward, J.M.; Schrempf, H. (1985). Isolation of Streptomyces "Total" DNA: Procedure 3. Genetic Manipulation of Streptomyces: A laboratory manual. John Innes Foundation, Norwich, UK, p. 77-78.

13. Küster, E. (1959a). Outline of a comparative study of criteria used in characterization of the actinomycetes. Intern. Bull. Bact. Nomen. Taxon., 9, 98-104.

14. Mahadevan B.; Crawford D.L. (1997). Properties of the chitinase of the antifungal biocontrol agent Streptomyces lydicus WYEC108. Enzyme Microb. Technol., 20, 489-493.
15. Pridham, T.G.; Anderson, P.; Foley, C.; Lindenfelser, L.A.; Hesseltine, C.W.; Benedit, R.G. (1956-57). A selection of media for maintenance and taxonomic study of Streptomyces. Antibiotics Ann., P.947-953.

16. Tokala, R.K.; Strap, J.L.; Jung, C.M.; Crawford, D.L.; Salove, M.H.; Deobald, L.A.; Bailey, J.F.; Morra, M.J. (2002) Novel plant-microbe Rhizosphere interaction involving Streptomyces lydicus WYEC108 and the pea plant (pisum sativum). Appl. Environ. Microbiol., 68, 2161-2171.

17. Ruan, J.S. (1977). The basis of taxonomy of actinomycetes. The Chinese Academic Press, Beijing. p. 139-146.

18. Shen, Y.C. (1997). Recent progress on the research and development in agricultural antibiotic. Plant Prot. Technol. Ext., 17, 35-37.

19. Shirling, E.B.; Gottlieb, D. (1966). Methods for characterization of Streptomyces species. Int. J. Syst. Bacteriol., 16, 313-340.

20. Siddhikol, C.; Erbstoeszer, J.W.; Weisblum, B. (1969). Mode of action of streptolydigin. J. Bacteriol., 99, 151-155.

21. Singh, S.K.; Gurusiddaiah S. (1984). Production, purification, and characterization of chandramycin, a polypeptide antibiotic from Streptomyces lydicus. Antimicrob. Agent Chemother., 26, 394-400.

22. Soares, A.C.F.; Sousa, C.S.; Garrido, M.S.; Perez, J.O.; Santos de Almeida, N. (2006). Soil streptomycetes with in vitro activity against the yam pathogens Curvularia eragrostides and Colletotrichum gloeosporioides. Braz. J. Microbiol., 37,456-461

23. Suh, H.W., (1992). Streptomyces WYEC108 as a bio-control agent against Pythium seed rot and emergence damping-off. Ph.D. thesis. University of Idaho, Moscow.

24. Tong, Y.H.; Ji, Z.L.; Xu, J.Y.; Chen, X.J. (2003). Research progress on biocontrol of gray mould. Chin. J. Biol. Control., 19, 131-135.

25. Valgas, C.; Machado de Souza, S.; Smania, E.F.A.; Smanis, Jr. A. (2007). Screening methods to determine antibacterial activity of natural products. Braz. J. Microbial., 38, 369-380.

26. Vining, L.C. (1990). Function of secondary metabolites. Annu. Rev. Microbial., 44, 395-427.

27. Yuan, W.M.; Crawford, D.L. (1995). Characterization of Streptomyces lydicus WYEC108 as a potential biocontrol agent against fungal root and seed rot. Appl. Environ. Microbial., 61, 3119-3128.

28. Zhang, Z.; Li, J.M.; Song, Y.; Yun, M.F.; Xu, H.J.; Zhou, Y.J. (2005). An overview on the gray mould (Botrytis cinerea) and the control of it in tomato. J. Inner Mongolia Agri. Uni., 26, 125-128.

29. Zhao, L.; Yang, H.T. (1999). Screening of biocontrol strains against vegetable gray mould and their bio-control efficiency. Chin. J. Appl. Environ. Biol., 5, 85-88. 